\title{
Necessity of Technical Training for Trainees in Industries for Achieving Flawless Production
}

\author{
J. Kannan, D. Venkatrama Raju,
}

\begin{abstract}
HRD training is a short term process utilizing a systematic and organized procedure by which both executive and non-executive personals acquire technical knowledge and skill for specific purposes. Thus, training is the basic and strong mechanism of HRD, which contributes directly to the individual development. It is a process of skill building of a man /women and its is for increasing the ability and effectiveness to perform his / her present and future tasks. HRD a newly adopted mantra and popular approach in the modern world. It is concerned with the development of people working at all levels ie. workers, technical staff and executives in an organization. This development can be mainly achieved through well-organized training programs. It is exceptionally appropriate to take note of that this measurement might be noteworthy. In any case, the vital point is that one needs to pass judgment on the nature of preparing inputs result relationship is to be thinks about. However, it isn't in a large portion of the organizations. Additionally it is to be seen if these preparation Programs are helping the representatives as an individual and as a component of the association. Usually in almost all the organization, other than some on-the-spot evaluation, a specific evaluation of the training programs is very rare. So it is necessary to find out whether the benefits of the training programs have reached the employees, in terms of the objectives of the training programs.
\end{abstract}

Keywords - HRD, Evaluation, Training programs

\section{INTRODUCTION}

The Human Resources of an organization is the most complex factor of an organization. The ability of human resources to manipulate and improve technology as well as structure makes it the dominant actor in any organization[1]-[3]. The individual in any organization come from varying social status characterized by different numbers. They enter with personalities shaped by competence, experience, psychological needs and expectations all inter linked and undergoing a continue changes due to the process of adjustment. Organization cannot avoid the impact of dynamic and fast changing world for the success of an organization, it is necessary for it to be dynamic. To cope up with the changing world, organization has to change the approaches of working culture through HRD. Human Resources are the most important assets in an organization because motivated human resources can better

Revised Manuscript Received on December 16, 2019

J. Kannan, Department of Science and Humanities, Bharath Institute of Higher Education and Research, Chennai , India. Email: sjkannan1986@gmail.com

D. Venkatrama Raju, Department of Science and Humanities, Bharath Institute of Higher Education and Research, Chennai, India. Email: prof.dvraju@gmail.com utilize all the natural resources[4]. Hence there is a need to invest time, money and effort towards the development of Human Resources. Training can involve the changing skills, knowledge, attitude or social behavior, training in an organization applies to operative and meddle level executive. New employees have to acquire latest skills and since the motivation is likely to be high at the time of joining the organization. They can be trained easily with the skills and behavior[5]-[8] expected in their position.

\section{OBJECTIVES}

- To find out whether the employees are satisfied with the training program.

- To find out whether the employees feel they need a training program.

- To find out the means to motivate the employees to achieve organizational goals.

- To find out the needs and the quality of the training imparted in the organization.

\section{A. Scope of the Study}

- This study can identify the employee's opinion on various dimensions about training programs of the company.

- The study can identify the employee's views further improving the training and development programs[9]-[14].

- The study can also reveal the facts about the training programs of the company which could give them a clear ideas about its features.

\section{B. Need for the Study}

1. To understand the importance of training, studying and conducting researches, on the topic are essential.

2. It will also provide information upon which to judge whether the resource currently employed in training could be used more effectively or not.

3. It is needed to bridge the gap between what the employees have and what the job demands[15]-[17].

4. It is the measurement of ultimate result of the contributions of the training program to the company goals like survival, growth, profitability, etc. and to the individuals goals like development of personality and social goals like maximizing social benefit.

\section{Statement of the Problem}

Workers are the best resource which helps with
accomplishing business 
destinations. To get best from representatives it is basic that they will be given fitting preparing on all parts of their work. Preparing is an incredible route for representative to adapt new aptitudes and information to fortify great work rehearses. Preparing has expanded in significance in the present condition where employments are perplexing and change quickly. After workers have been chosen for different positions in an association, preparing them for the particular undertakings to which they have been appointed accept incredible significance[18]-[20]. It is valid in numerous associations that before a worker is fitted into an agreeable working association with different representatives, he is given sufficient preparing. Preparing is the demonstration of expanding the learning and abilities of a representative for playing out a specific occupation. The significant result of preparing is learning. A learner adapts new propensities, refined abilities and valuable information during the preparation that encourages him improve execution. To endure and thrive in the present day corporate wilderness, organizations ought to put time and cash in redesigning the learning and aptitudes of their workers continually. In such conditions Rane Engine Valve Limited might want to know the requirements of the preparation program directed at REVL.

\section{RESULTS AND DISCUSSIONS}

$\square$ Most of the employees in the organization between the age group 36-45.

$\square$ It has been found that most of the employees in the company have at least Fifteen years of experience.

$\square$ It is seen most of the respondents are graduates.

$\square$ It has been found that $41 \%$ of the employees were highly satisfied with the training programs[21]-[22] .

$\square$ It has been inferred that most of the employee that the training program helps in better understanding between superior and sub-ordinate to perform better.

$\square$ The management of REVL arrange experienced faculty to conduct the training program successfully. In fact, the employees welcome this decision and appreciate their innovative training methods, good reading materials, reputed institutions and application of knowledge to increase the effectiveness of the training program.

$\square$ Most of the respondents in the organization were participated in discussion in assessing training needs so this helps to perform task effectively and helps them to handle job competently without any wastage.

$\square$ It is observed that most of the employee are satisfied with the guidance provided by the superior.

$\square$ Most of the respondents are satisfied with the knowledge gained from other department. This makes the employees mobile and versatile.

$\square$ It has been found that most of the respondents were gained in improving the personality, attitudes and abilities, technical skills, understanding behaviour . so a training program will go a long way in obtaining employee loyalty, support and commitment to company activities.

$\square$ It is observed from the study that $50 \%$ of the employee in the company have improved job effectiveness. This includes the manner and extent to which the trainee has applied his learning to his job.

$\square$ Most of the respondents were satisfied with the management recognize the improvement after training. it helps the trainee to modify the undesired or incorrect behaviour.

$\square$ It is been found that $42 \%$ of the employee strongly agree to take higher responsibility after training. This shows the confidence level of the employees to achieve the task effectively.

$\square$ It is inferred that most of the employee feels that no modification is necessary for the methods of training program conducted by the company.

$\square$ Most of the respondents inferred that they were satisfied with the objectives of the program been achieved. This enable an employee to do his present job more effectively.

$\square$ On application of Friedman Two-way ANOVA, as the calculated value of Chi-Square (27) falls beyond the critical value (7.815) into the rejection region the null hypothesis was rejected. This conforms that all four parameters have good sign for developing different skills through training program.

$\square$ On using Paired t test for comparing the two parameters which are content matches the job requirements and willingness to take higher responsibilities after training, the calculated $t$ value is 0.904 . This value fall within the critical region (the critical value was found to be 1.96 for $5 \%$ level of significance and n-1 degrees of freedom). This meant that we accept the null hypothesis (H0). Therefore it is proved that as the performance of the employee improves their job opportunity effectively.

$\square$ Two-way Analysis of Variance shows that there is no significant difference between years of experience \& awareness about the training program followed by REVL as calculated value (4.04) is lesser than table value (4.46). Hence he has more experience in his work and able to manage the work effectively.

$\square$ Correlation coefficient was used to analyze management recognize the improvement and willing to take higher responsibility after training. The value of $r$ is 0.548 which confirms that there is a relationship between both management recognize the improvement and willingness of the trainee. This confirms that work is done well which will lead to increase the confidence level among the employees .

$\square$ Chi-Square test done between participation in discussion in assessing training needs and training needs meets effectively. The calculated value(1.678) is less than the

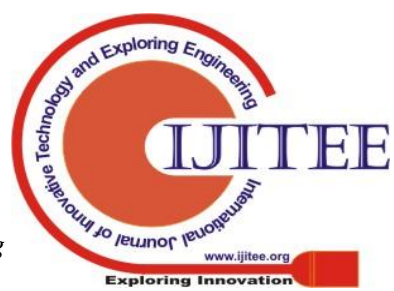


table value(5.991) thus the participation in discussion does not relate with the training needs to meet effectively .

\section{SUGGESTIONS}

$\square$ The researches was able to perceive through the analysis of data collected from the respondents that the employees has a positive attitude towards the training programs .However, the researcher has given the following recommendations to make existing training system even more effective to establish organizational development and to attain overall effectiveness . Training needs may be identified by individual concerned or departmental heads, but participation must be with the consent of the individual. If the training programs are intimated in advance, the participants can adjust or plan their work schedule accordingly[24]-[25].

$\square$ The improvement of training programs in future can be made if topics are dealt in depth and sufficient time is allotted for condition of training programs and to attend the training programs by the employees.

$\square$ The management may, if feasible, consider whether the employees/ participants should be consulted in formulating the training programs by adopting a proactive approach. The employees can be consulted more in identifying their training needs.

\section{CONCLUSION}

$\square$ The training program that is handled by competent personnel though not a completely perfect one, is found to have helped a major portion of the employees in performing their duties well with enhanced responsibilities. A few examples is to consolidate such a claim would be that the employees have learned about their work atmosphere and culture of the organization. The management spending time with the workers during the training is another factor that had been noticed.

$\square$ The degree of participation and development of different skills are considered and are found to be good. Considering all factors, it can be said that the effectiveness of training program is good on overall basis.

\section{REFERENCES}

1) Vasanthi, S. \& Rabiyathul Basariya, S. 2019, "Influence of value analysis and cross training in industry", International Journal of Engineering and Advanced Technology, vol. 8, no. 6, pp. 1810-1811.

2) Velvizhi, R., Sri Gowtham, S. \& Jeya Priya, D. 2019, "Examination of early feedbacks for effective product retailing on E-commerce websites", International Journal of Engineering and Advanced Technology, vol. 8, no. 6 Special Issue 2, pp. 703-706.

3) Anuradha, C., Pothumani, S. \& Kavitha, R. 2019, "A novel method towards E-commerce", International Journal of Engineering and Advanced Technology, vol. 8, no. 6 Special Issue 2, pp. 535-538.

4) Thomas, J. \& Rabiyathul Basariya, S. 2019, "A study on the issues of financial ratio analysis", Indian Journal of Public Health Research and Development, vol. 10, no. 3, pp. 1079-1081.

5) Ramachandran, S. \& Rabiyathul Basariya, S. 2019, "Online marketing study on customer satisfaction and relationship", Indian Journal of Public Health Research and Development, vol. 10, no. 3, pp. 1072-1078.

6) Priya, R., Vinothini, G. \& Cor Jesu, C.D. 2019, "The mentor-protégé relationship for professional growth", Journal of Advanced Research in Dynamical and Control Systems, vol. 11, no. 9 Special Issue, pp. 1110-1119.

7) Jannifer Rani, N., Bina Pani, S. \& Nimisha, N.S. 2019, "A study on money back polices available in LIC", Journal of Advanced Research in Dynamical and Control Systems, vol. 11, no. 9 Special Issue, pp. 833-839.
8) Saillaja, V., Jhansi Rani, K. \& Catherine, R. 2019, "Global marketing management planning and organization", Journal of Advanced Research in Dynamical and Control Systems, vol. 11, no. 9 Special Issue, pp. 489-493.

9) Saillaja, V., Jhansi Rani, K. \& Catherine, R. 2019, "The new phase of marketing information system", Journal of Advanced Research in Dynamical and Control Systems, vol. 11, no. 9 Special Issue, pp. 482-488.

10) Thoufiqulla \& Raju, D.V. 2019, "Perception of indian investor towards investment in mutual funds with special reference to mip funds", Journal of Advanced Research in Dynamical and Control Systems, vol. 11, no. 5, pp. 177-183.

11) Jasmine, K.R.M. \& Basariya, S.R. 2018, "A study on the customers benefits on mutual funds", International Journal of Civil Engineering and Technology, vol. 9 , no. 4, pp. 45-48.

12) Vasanthi, S. \& Basariya, S.R. 2019, "Pros and cons of on the job training versus off the job training", International Journal of Scientific and Technology Research, vol. 8, no. 10, pp. 671-674.

13) Pavithra, J. \& Ganesan, M. 2016, "A study on awareness and impact of micro-financial schemes", International Journal of Applied Business and Economic Research, vol. 14, no. 8, pp. 5449-5460.

14) Pavithra, J., Dilli Babu, P. \& Ambuli, T.V. 2014, "A study on budgetary control at Maruti Service Masters, Chennai", International Journal of Applied Business and Economic Research, vol. 12, no. 2, pp. 151-161.

15) Gunaraja, T.M. \& Venkatrama Raju, D. 2018, "Determining factors of organisational climate with reference to leadership styles", International Journal of Mechanical Engineering and Technology, vol. 9, no. 9, pp. 1327-1332.

16) Gunaraja, T.M. \& Venkatrama Raju, D. 2018, "The role of job satisfaction and training of employees in determining organisational climate of a selected industry", International Journal of Civil Engineering and Technology, vol. 9, no. 8, pp. 1266-1269.

17) Aarathy, T.S. \& Raju, D.V. 2018, "Performance appraisal and its effects on employees with respect to it sector in Chennai city", International Journal of Civil Engineering and Technology, vol. 9, no. 6, pp. 1535-1538.

18) Aarathy, T.S. \& Raju, D.V. 2018, "Employee perception towards performance appraisal system in IT sector", International Journal of Mechanical Engineering and Technology, vol. 9, no. 5, pp. 131-135.

19) Porselvi, W., Jublee, D. \& Sivanesan, G. 2018, "A study on factors influencing adoption of technology and innovation in banking industry, tamilnadu, India", International Journal of Mechanical Engineering and Technology, vol. 9, no. 5, pp. 789-800.

20) Akessa, G.M. and Dhufera, A.G., 2015. Factors That Influences Students Academic Performance: A Case of Rift Valley University, Jimma, Ethiopia. Journal of Education and Practice, 6(22), pp.55-63.

21) Miller, G. and Shih, C.C., 1999. A faculty assessment of the academic rigor of on-and off-campus courses in agriculture. Journal of Agricultural Education, 40, pp.57-65.

22) Tsinidou, M., Gerogiannis, V. and Fitsilis, P., 2010. Evaluation of the factors that determine quality in higher education: an empirical study. Quality Assurance in education, 18(3), pp.227-244.

23) Farooq, M.S., Chaudhry, A.H., Shafiq, M. and Berhanu, G., 2011. Factors affecting students' quality of academic performance: a case of secondary school level. Journal of quality and technology management, 7(2), pp.1-14.

24) Fitsilis, P., Gerogiannis, V. and Anthopoulos, L., 2014. Ontologies for software project management: a review. Journal of Software Engineering and Applications, 7(13), p.1096.

25) Adams, J.D. and Jaffe, A.B., 1996. Bounding the effects of R\&D: an investigation using matched establishment-firm data(No. w5544). National bureau of economic research.

\section{AUTHORS PROFILE}

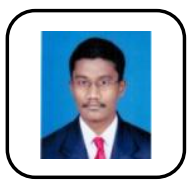

J.Kannan Associate Professor, Department of Science and Humanities, Bharath Institute of Higher Education and Research, Chennai, India.

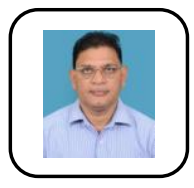

D. Venkatrama Raju Professor, Department of Science and Humanities, Bharath Institute of Higher Education and Research, Chennai, India. 